[Chem. Pharm. Bull.

36(12)4700-4705(1988)

\title{
New Steroidal Alkaloids from the Chinese Herb Drug, "Bei-mu"
}

\author{
Kô Kaneko, ${ }^{* a} a$ Takao Katsuhara, ${ }^{a}$ Yukie Kitamura, ${ }^{a}$ \\ Makoto Nishizawa, ${ }^{a}$ Yuh-Pan Chen, ${ }^{b}$ \\ and HONG-YEN HSU ${ }^{b}$ \\ Faculty of Pharmaceutical Sciences, Hokkaido University, ${ }^{\text {Kita-12-jo }}$ \\ Nishi-6-chome Kita-ku, Sapporo 060, Hokkaido, Japan, Oriental \\ Healing Arts Institute, 1945 Palo Verde Avenue, Suite 208, \\ Long Beach, California 90815, U.S.A.
}

(Received April 28, 1988)

\begin{abstract}
Three new steroidal alkaloids were isolated from the bulbs of Fritillaria delavayi Franch. The structures of delafrinone (1), delafrine (2) and the third alkaloid were deduced to be $(22 S, 25 S)$ $3 \beta, 16 \beta$-dihydroxy- $5 \alpha$-cevanin-6-one, $(22 S, 25 S)$-5 $\alpha$-cevanine- $3 \beta, 6 \beta, 16 \beta$-triol and $(22 R, 25 S)$-solanid5 -enine- $3 \beta, 5 \alpha, 6 \beta$-triol (3), respectively, on the basis of spectral data and chemical evidence.
\end{abstract}

Keywords_—Fritillaria delavayi; Liliaceae; steroidal alkaloid; D/E trans-5 $\alpha$-cevanine, solanid5-enine-3 $\beta, 5 \alpha, 6 \beta$-triol

"Bei-mu" is the dried bulb of Fritillaria species (Liliaceae) and has been used as an antitussive and expectorant in traditional Chinese medicine. ${ }^{1)}$ In China, many kinds of Fritillaria species have been identified taxonomically, and the bulbs from these different species have been used for the same medicinal purpose. What we need now is to make clear the differences in the constituents and pharmacological effects among these Fritillaria species. We have reported the identification of isoverticine, ${ }^{2)}$ baimonidine, ${ }^{2)}$ isobaimonidine, ${ }^{3)}$ and fritillarizine, ${ }^{4)}$ in addition to verticine, verticinone, hapepunine, ${ }^{5)}$ and solanidine from Fritillaria verticillata. Recently, we have been studying the alkaloids of some Chinese "Beimu" and have reported new alkaloids from "Chuan bei-mu" ( $F$. delavayi FRANCH), i.e., delavine (4), ${ }^{6)}$ delavinone (5), ${ }^{6}$ and chuanbeinone (6), ${ }^{7)}$ which belong to the 20 -deoxy-D/E cis$5 \alpha$-cevanine alkaloid group. In this paper, we describe additional new alkaloids from the same source.

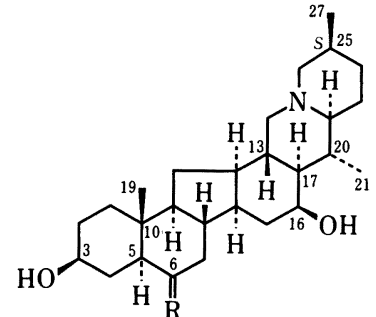

delafrinone (1): $\mathrm{R}=\mathrm{O}$

delafrine (2): $\mathrm{R}: \stackrel{\mathrm{OH}}{\mathrm{H}}$

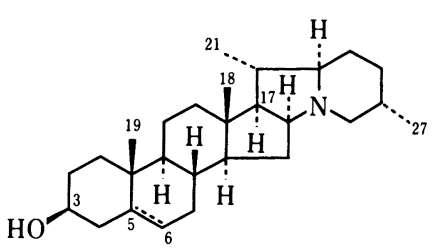

solanidine $(7): \Delta_{5}$

compound $3: 5 \alpha-\mathrm{OH}, 6 \beta-\mathrm{OH}$

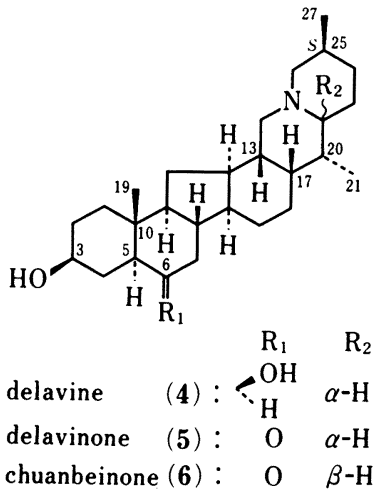

chuanbeinone (6): $0 \quad \beta-\mathrm{H}$

Fig. 1 


\section{Results and Discussion}

Delafrinone (1), $[\alpha]_{\mathrm{D}}-58.9^{\circ}\left(c=0.58, \mathrm{CHCl}_{3}\right), \mathrm{C}_{27} \mathrm{H}_{43} \mathrm{NO}_{3}$, was obtained as colorless needles from $\mathrm{MeOH}$. The mass spectrum (MS) of 1 revealed the molecular ion $\left(\mathrm{M}^{+}\right)$at $m / z$ 429 and the base peak at $m / z 111$, which is a typical fragment ion of $5 \alpha$-cevanine alkaloids lacking the hydroxyl group at C-20. $\left.{ }^{8}\right)$ The proton nuclear magnetic resonance $\left({ }^{1} \mathrm{H}-\mathrm{NMR}\right)$ spectrum of 1 exhibited the signals of two secondary methyl groups at $\delta 0.90$ and 1.14 , a tertiary methyl signal at $\delta 0.50$, and two methine protons on carbon bearing a hydroxyl group at $\delta 3.80$ and 4.25 . The assignment of the carbon- 13 nuclear magnetic resonance $\left({ }^{13} \mathrm{C}-\mathrm{NMR}\right)$ signals (Table I) was made with the aid of the INEPT procedure.

A tertiary methyl signal (19-Me) was shifted upfield to $\delta 0.50\left(\right.$ in $\mathrm{C}_{5} \mathrm{D}_{5} \mathrm{~N}$ ), because of the presence of the keto group at C-6 $\left(\delta 211.3\right.$ and $v_{\max } 1710 \mathrm{~cm}^{-1}$ in the ${ }^{13} \mathrm{C}-\mathrm{NMR}$ and infrared (IR) spectra) as in verticine ${ }^{5)}$ and imperialine. ${ }^{9)}$ In the ${ }^{1} \mathrm{H}-\mathrm{NMR}$ spectrum of 1 , the secondary methyl signal at $\delta 1.14$ showed the presence of a $\beta$-axial methyl group at C-25. The signal at $\delta 0.90$, ascribable to the methyl group at C-20, further supported the absence of a hydroxyl group at C-20. A multiplet centered at $\delta 3.80\left(W_{1 / 2}=24 \mathrm{~Hz}\right)$ was associated with the $\alpha$ hydrogen at C-3 bearing a hydroxyl group (this signal was shifted downfield to $\delta 4.69$ on acetylation). Another multiplet centered at $\delta 4.25\left(W_{1 / 2}=8 \mathrm{~Hz}\right.$, this signal was shifted downfield to $\delta 5.22$ on acetylation) could be due to $\mathrm{H}_{2 \alpha}, \mathrm{H}_{4 \alpha}, \mathrm{H}_{23 \alpha}, \mathrm{H}_{24 \beta}, \mathrm{H}_{15 \beta}$ (D/E trans), $\mathrm{H}_{15 \alpha}(\mathrm{D} / \mathrm{E}$ cis $), \mathrm{H}_{16 \beta}(\mathrm{D} / \mathrm{E}$ cis $)$, or $\mathrm{H}_{16 \alpha}(\mathrm{D} / \mathrm{E}$ trans $)$, from its narrow half height width $\left(W_{1 / 2}=\right.$

TABLE I. ${ }^{13}$ C-NMR Spectra Data $(\mathbf{1}, \mathbf{2}, \mathbf{5})^{a)}$

\begin{tabular}{|c|c|c|c|c|}
\hline $\begin{array}{c}\text { Carbon } \\
\text { No. }\end{array}$ & $\begin{array}{c}\mathrm{D} / \mathrm{E} \text { trans } \\
\text { Verticinone }\end{array}$ & $\begin{array}{c}\mathrm{D} / \mathrm{E} c i s \\
\mathbf{5}\end{array}$ & 1 & 2 \\
\hline 1 & 37.1 & 37.6 & 36.9 & $39.4^{b)}$ \\
\hline 2 & 30.5 & 30.6 & 30.5 & 32.4 \\
\hline 3 & 70.9 & 70.9 & 71.7 & 71.7 \\
\hline 4 & 30.1 & 30.3 & 30.2 & $36.0^{c)}$ \\
\hline 5 & 56.5 & 56.7 & 56.9 & 49.5 \\
\hline 6 & 211.0 & 211.0 & 211.3 & 72.2 \\
\hline 7 & 46.0 & 47.0 & 45.9 & $39.7^{b)}$ \\
\hline 8 & 42.1 & 39.7 & 43.0 & 41.0 \\
\hline 9 & 56.7 & 56.7 & 56.9 & 58.8 \\
\hline 10 & 38.4 & 38.3 & 38.3 & $36.5^{c)}$ \\
\hline 11 & 29.4 & 30.0 & 29.0 & 30.5 \\
\hline 12 & 41.1 & 39.5 & 40.2 & 38.0 \\
\hline 13 & 39.3 & 39.3 & 36.9 & 37.3 \\
\hline 14 & 43.5 & 41.0 & 43.4 & 43.5 \\
\hline 15 & 24.7 & 26.8 & 31.5 & 32.9 \\
\hline 16 & 20.6 & 17.1 & 65.1 & 64.8 \\
\hline 17 & 48.8 & 46.9 & 49.6 & 50.5 \\
\hline 18 & 61.8 & 59.3 & 61.4 & 62.3 \\
\hline 19 & 12.8 & 12.7 & 12.9 & 15.0 \\
\hline 20 & 71.0 & 35.7 & 36.0 & $36.5^{c)}$ \\
\hline 21 & 20.4 & 15.6 & 14.0 & 14.6 \\
\hline 22 & 70.3 & 62.4 & 68.3 & 69.6 \\
\hline 23 & 19.1 & 24.9 & 25.1 & 25.8 \\
\hline 24 & 29.2 & 30.4 & 28.9 & 29.9 \\
\hline 25 & 27.7 & 28.4 & 28.4 & 28.7 \\
\hline 26 & 62.3 & 61.8 & 61.5 & 62.7 \\
\hline 27 & 17.3 & 18.3 & 18.2 & 18.2 \\
\hline
\end{tabular}

a) Spectra were measured in $\mathrm{CDCl}_{3}$, except for $\left.2\left(\mathrm{C}_{5} \mathrm{D}_{5} \mathrm{~N}\right) . \quad b, c\right)$ Assignments may be interchanged in each column. 
$8 \mathrm{~Hz}$ ). The ${ }^{1} \mathrm{H}$ - and ${ }^{13} \mathrm{C}-\mathrm{NMR}$ spectra of 1 were inconsistent with $\mathrm{H}_{2 \alpha}$, and $\mathrm{H}_{4 \alpha}$ because of the highfield-shifted 19-Me $\left(\delta 0.50\right.$, in $\left.\mathrm{C}_{5} \mathrm{D}_{5} \mathrm{~N}\right)$, while $\mathrm{H}_{23 \alpha}$ and $\mathrm{H}_{24 \beta}$ were ruled out by the base peak at $m / z 111$, and $\mathrm{H}_{15 \alpha}$ and $\mathrm{H}_{16 \beta}$ because of the $\mathrm{D} / \mathrm{E}$ trans juncture in 1 which is indicated by the downfield-shifted C-18 $(\delta 61.4)$ and C-22 $(\delta 68.3)$ compared with those of a D/E cis-5 $\alpha$ cevanine alkaloid (Table I).

The remaining possibilities, $\mathrm{H}_{15 \beta}$ or $\mathrm{H}_{16 \alpha}$, were examined by ${ }^{1} \mathrm{H}-{ }^{1} \mathrm{H}$-two dimensional shift correlation $\left({ }^{1} \mathrm{H}-{ }^{1} \mathrm{H}\right.$ 2D-COSY) spectroscopy and ${ }^{1} \mathrm{H}-{ }^{13} \mathrm{C}$-relayed-2D-COSY spectroscopy.

The ${ }^{1} \mathrm{H}-{ }^{1} \mathrm{H}$ 2D-COSY spectrum of 1 showed several cross peaks (Fig. 2). The $\mathrm{Me}_{21}$ at $\delta 0.90$ was coupled with a proton $(\delta 1.78)$ and this proton also coupled with another proton $(\delta 0.78)$. This arrangement can only correspond to the $\mathrm{Me}_{21}-\mathrm{H}_{20}-\mathrm{H}_{17}$ linkage. The resonances of $\mathrm{Me}_{27}$ which form an isolated set, may be easily identified. The remaining multiplet at $\delta 4.25$ in question, coupled with three protons at $\delta 1.72,2.15$ and 0.78 , corresponds to $\mathrm{H}_{15 x, \beta^{-}} \mathrm{H}_{16 x^{-}}$ $\mathrm{H}_{17}$. In addition, the COSY procedure gives unequivocally the $\mathrm{H}_{15 \alpha, \beta}-\mathrm{H}_{16 \alpha}-\mathrm{H}_{17}-\mathrm{H}_{20}-\mathrm{Me}_{21}$ sequence.

$\mathrm{H}_{13 \beta}-\mathrm{H}_{18 \alpha, \beta}$

The signals of $\mathrm{H}_{17}$, observed as a triplet of doublets $(J=2,9,9 \mathrm{~Hz})$, also supported these connectivities, the $\mathrm{D} / \mathrm{E}$ trans juncture, and the orientation of the hydroxyl group at $\mathrm{C}-16$ as $\beta$.

The ${ }^{1} \mathrm{H}-{ }^{13} \mathrm{C}$ relayed $2 \mathrm{D}-\mathrm{COSY}$ spectrum of 1 supported the deductions made from the ${ }^{1} \mathrm{H}-{ }^{1} \mathrm{H}$ 2D-COSY spectrum.

Thus, the structure of 1 was determined as $(22 S, 25 S)-3 \beta, 16 \beta$-dihydroxy-5 $\alpha$-cevanin-6one.

Delafrine (2), $[\alpha]_{\mathrm{D}}-39.9^{\circ}\left(c=0.50, \mathrm{CHCl}_{3}\right), \mathrm{C}_{27} \mathrm{H}_{45} \mathrm{NO}_{3}$, was obtained as a powder. The MS of 2 revealed ion peaks at $m / z 431\left(\mathrm{M}^{+}\right), 416$, and 111 (base peak) and the $\mathrm{M}^{+}$ion peak was 2 mass units larger than that of $\mathbf{1}$. The infrared (IR) spectrum of 2 did not show any carbonyl absorption. The ${ }^{1} \mathrm{H}-\mathrm{NMR}$ spectrum of 2 exhibited three methyl signals at $\delta 0.92$ (d), $1.09(\mathrm{~s})$, and $1.12(\mathrm{~d})$, and three methine protons on carbon bearing a hydroxyl group at $\delta 3.94,4.07$, and 4.30 . The signals of these methine protons were shifted downfield to $\delta 4.70$,

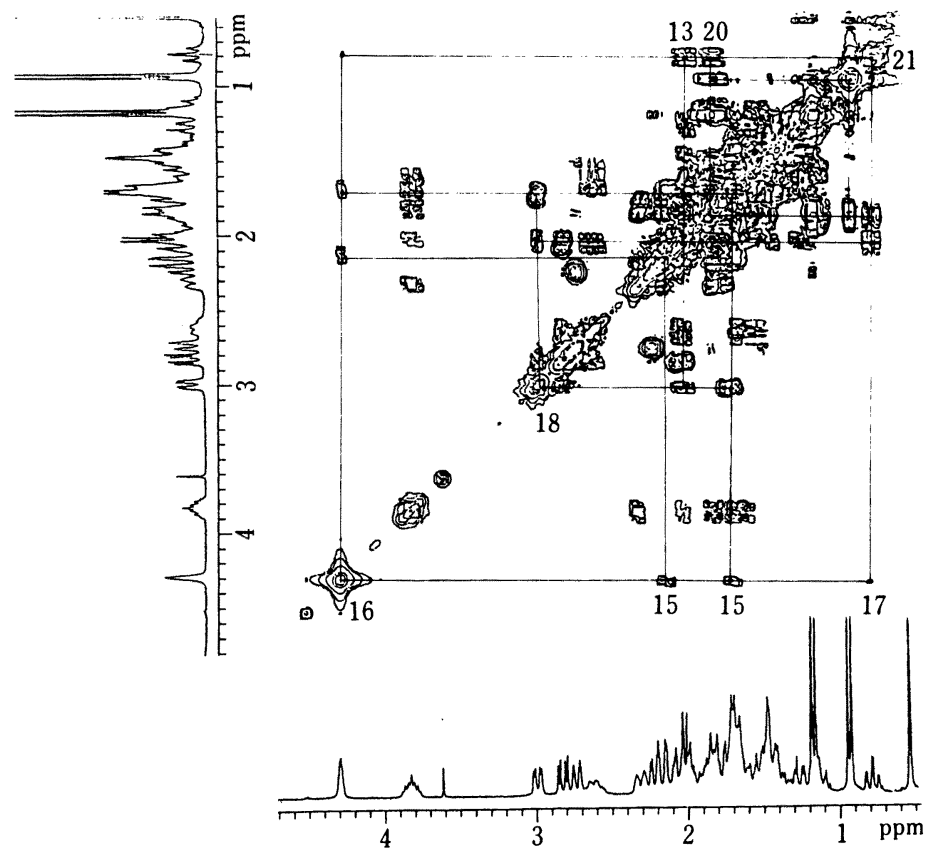

Fig. 2. ${ }^{1} \mathrm{H}-{ }^{1} \mathrm{H}$ 2D-COSY Spectrum of Delafrinone (1) $\left(\mathrm{C}_{5} \mathrm{D}_{5} \mathrm{~N}, 270 \mathrm{MHz}\right)$ 


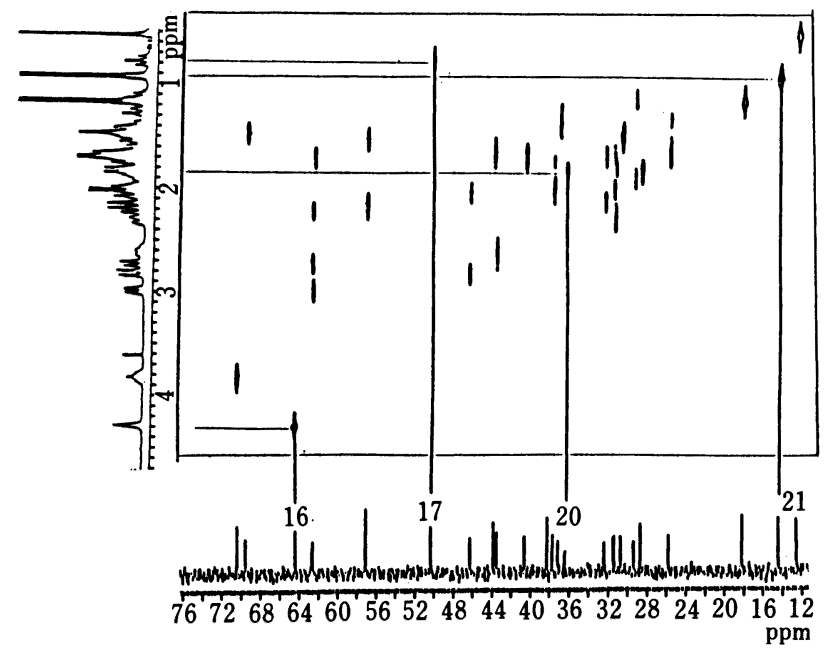

Fig. 3. ${ }^{1} \mathrm{H}-{ }^{13} \mathrm{C}$ 2D-COSY Spectrum of Delafrinone (1) $\left(\mathrm{C}_{5} \mathrm{D}_{5} \mathrm{~N}, 270 \mathrm{MHz}\right)$

5.09 and 5.21 on acetylation. Comparing the chemical shifts and $W_{1 / 2}$ values with those of 2 and delavine (4), the signals at $\delta 3.94,4.07$, and 4.30 were associated with $3 \alpha-\mathrm{H}, 6 \alpha-\mathrm{H}$, and $16 \alpha-\mathrm{H}$, respectively. From these results, 2 was assumed to be a $6 \beta-\mathrm{OH}$ derivative of 1 . To confirm this, 1 was converted to 2 by reduction with $\mathrm{NaBH}_{4}$ in EtOH. The physical constants of the reduction product agreed well with those of 2 . Thus 2 was identified as $(22 S, 25 S)-5 \alpha-$ cevanine- $3 \beta, 6 \beta, 16 \beta$-triol. Compounds 1 and 2 are the first examples of 20-deoxy-16-hydroxy$5 \alpha$-cevanine alkaloids.

Compound 3 was obtained as a white powder, and afforded a diacetate (3b) on acetylation in pyridine. The MS of 3 revealed ion peaks at $m / z 431\left(\mathrm{M}^{+}\right), 204$, and 150 (base peak), which correspond to the diagnostic fragment ions of solanidane alkaloids. ${ }^{10)}$ The ${ }^{1} \mathrm{H}$ and ${ }^{13} \mathrm{C}$-NMR spectra showed the absence of an olefin moiety in 3. In the ${ }^{1} \mathrm{H}-\mathrm{NMR}$ spectrum of 3, one methine proton on carbon bearing a hydroxyl group was observed at $\delta 4.14$, which was assigned to $6 \alpha-\mathrm{H}$. Another methine proton on carbon bearing a hydroxyl group gave a signal overlapping with the signal of $\mathrm{H}_{2} \mathrm{O}$, but 3-diacetate showed the corresponding proton at $\delta 5.12\left(W_{1 / 2}=22 \mathrm{~Hz}\right)$, and it can be assigned as $\mathrm{H}_{3 \alpha}$. The singlet methyl signal at $\delta 1.63$ was shifted downfield compared with that of solanidine (7). The IR spectrum of the diacetate of 3 showed the absorption of a hydroxyl group. Therefore, 3 was assumed to be a glycol of solanidine.

In order to establish the structure of 3 , solanidine (7) was treated with performic acid followed by alkaline treatment. ${ }^{11)}$ The physical and spectral data of the product agreed with those of 3 . Thus, 3 was identified as $(22 R, 25 S)$-solanid-5-enine- $3 \beta, 5 \alpha, 6 \beta$-triol.

When solanidine (7) was refluxed with methanolic $\mathrm{HCl}$ for $6 \mathrm{~h}$, it was recovered quantitatively. Thus, compound $\mathbf{3}$ is the first example of a natural solanidanine alkaloid with a glycol moiety at the $\mathrm{A}$ and $\mathrm{B}$ rings.

\section{Experimental}

Melting points were determined on a Kofler hot-stage apparatus and are uncorrected. Optical rotations were measured with a JASCO DIP-4 digital polarimeter. IR spectra were recorded on a JASCO A-102 spectrometer. ${ }^{1} \mathrm{H}$ NMR spectra were run on a JEOL JNM FX-100 (100 MHz), GX-270 (270 MHz), or GX-500 (500 MHz) spectrometer in $\mathrm{CDCl}_{3}$ or $\mathrm{C}_{5} \mathrm{D}_{5} \mathrm{~N}$ solution and ${ }^{13} \mathrm{C}-\mathrm{NMR}$ spectra on a JEOL FX-90Q $(22.5 \mathrm{MHz})$ spectrometer in $\mathrm{CDCl}_{3}$ or $\mathrm{C}_{5} \mathrm{D}_{5} \mathrm{~N}$ solution with tetramethylsilane (TMS) as an internal standard. Electron impact mass spectrometry 
(EI-MS) was done with a JEOL JMS-D-300 machine. Thin layer chromatography (TLC) was performed on Merck precoated plates, Kieselgel $60 \mathrm{~F}_{254}$. Column chromatography was carried out on Wakogel C-300 (300 mesh).

Isolation-Dried bulbs $(4.6 \mathrm{~kg})$ of $F$. delavayi $\mathrm{FRANCH}$, obtained in China, were powdered and extracted four times with three liters of methanol. After concentration, the extract was dissolved in water, washed once with $500 \mathrm{ml}$ hexane to remove fatty substances $(3.17 \mathrm{~g})$, and then applied to a column $(5 \mathrm{~cm} \times 40 \mathrm{~cm})$ of Diaion HP-20 (Mitsubishi Kasei Co., Ltd.). The column was eluted with $\mathrm{H}_{2} \mathrm{O}$-methanol using increasing $\mathrm{MeOH}$ concentration. The alkaloidscontaining fractions $(20-100 \% \mathrm{MeOH})$ were combined and concentrated $(7.98 \mathrm{~g})$.

The combined alkaloids-containing fraction $(7.98 \mathrm{~g})$ was hydrolyzed with $1 \mathrm{~N}$ methanolic $\mathrm{HCl}(120 \mathrm{ml})$ for $6 \mathrm{~h}$, and followed by usual work-up to afford $960 \mathrm{mg}$ of crude alkaloid. The crude alkaloid was fractionated by repeated silica gel column chromatography using the solvent systems of hexane-EtOH-Et ${ }_{2} \mathrm{NH}(9: 0.75: 0.75)$ and cyclohexane-EtOAc-MeOH $(2: 2: 1)$. Delafrinone $(1,22.2 \mathrm{mg})$, delafrine $(2,11 \mathrm{mg})$, and compound 3 (15 mg) were obtained along with solanidine $(7,164 \mathrm{mg})$, imperialine $(11.2 \mathrm{mg})$, delavine $(4,13.2 \mathrm{mg})$, delavinone $(5,16.6 \mathrm{mg})$, and chuanbeinone $(6,115 \mathrm{mg})$.

Delafrinone (1) Colorless needles from $\mathrm{MeOH}, \mathrm{mp} 134-136^{\circ} \mathrm{C},[\alpha]_{\mathrm{D}}-58.9^{\circ}\left(c=0.58, \mathrm{CHCl}_{3}\right), \mathrm{C}_{27} \mathrm{H}_{43} \mathrm{NO}_{3}$ (obsd. 429.3229, calcd. 429.3241). MS m/z: $429\left(\mathrm{M}^{+}\right), 414\left(\mathrm{M}^{+}-\mathrm{CH}_{3}\right), 373,111$ (base peak). IR $v_{\max }^{\mathrm{CHCl}_{3}} \mathrm{~cm}^{-1}: 3400$ $(\mathrm{OH}), 2770$ (trans-quinolizidine), ${ }^{12)} 1704(\mathrm{C}=\mathrm{O}) .{ }^{1} \mathrm{H}-\mathrm{NMR}\left(100 \mathrm{MHz}, \mathrm{CDCl}_{3}\right) \delta: 0.76(3 \mathrm{H}, \mathrm{s}, 19-\mathrm{H}), 0.86(3 \mathrm{H}, \mathrm{d}$, $J=6 \mathrm{~Hz}, 21-\mathrm{H}), 1.08(3 \mathrm{H}, \mathrm{d}, J=7 \mathrm{~Hz}, 27-\mathrm{H}), 3.57\left(1 \mathrm{H}, \mathrm{m}, W_{1 / 2}=24 \mathrm{~Hz}, 3 \alpha-\mathrm{H}\right), 4.08\left(1 \mathrm{H}, \mathrm{m}, W_{1 / 2}=8 \mathrm{~Hz}, 16 \alpha-\mathrm{H}\right) .{ }^{13} \mathrm{C}-$ $\operatorname{NMR}\left(22.5 \mathrm{MHz}, \mathrm{CDCl}_{3}\right) \delta: 36.9(\mathrm{t}, \mathrm{C}-1), 30.5$ (t, C-2), 71.0 (d, C-3), 30.2 (t, C-4), 56.9 (d, C-5), $211.3(\mathrm{~s}, \mathrm{C}-6), 45.9(\mathrm{t}$, C-7), 43.0 (d, C-8), 56.9 (d, C-9), 38.3 (s, C-10), 29.4 (t, C-11), 40.2 (d, C-12), 36.9 (d, C-13), 43.4 (d, C-14), 31.5 (t, C15), 65.1 (d, C-16), 49.6 (d, C-17), 61.4 (t, C-18), 12.9 (q, C-19), 36.0 (d, C-20), 14.0 (q, C-21), 68.3 (d, C-22), 25.1 (t, C23), 28.9 (t, C-24), 28.4 (d, C-25), 61.5 (t, C-26), 18.2 (q, C-27).

Acetylation of 1 to the Diacetate (1b)-Delafrinone $(15.0 \mathrm{mg})$ was acetylated in the usual manner to give $14.0 \mathrm{mg}$ of $1 \mathrm{~b}, \mathrm{mp} 138-140^{\circ} \mathrm{C}$. IR $v_{\max }^{\mathrm{CHCl}_{3}} \mathrm{~cm}^{-1}: 1720(-\mathrm{C}=\mathrm{O},-\mathrm{COO})$. MS $m / z: 513\left(\mathrm{M}^{+}\right), 498,454,111$ (base peak). ${ }^{1} \mathrm{H}-\mathrm{NMR}\left(100 \mathrm{MHz}, \mathrm{CDCl}_{3}\right) \delta: 0.79(3 \mathrm{H}, \mathrm{s}, 19-\mathrm{H}), 0.81(3 \mathrm{H}, \mathrm{d}, J=6 \mathrm{~Hz}, 21-\mathrm{H}), 1.10(3 \mathrm{H}, \mathrm{d}, J=7 \mathrm{~Hz}, 27-\mathrm{H}), 2.00$ (3H, s, -OAc), $2.03(3 \mathrm{H}, \mathrm{s},-\mathrm{OAc}), 4.69\left(1 \mathrm{H}, \mathrm{m}, W_{1 / 2}=24 \mathrm{~Hz}, 3 \alpha-\mathrm{H}\right), 5.22\left(1 \mathrm{H}, \mathrm{m}, W_{1 / 2}=8 \mathrm{~Hz}, 16 \alpha-\mathrm{H}\right)$.

Delafrine (2)- $\mathrm{mp} 269-272^{\circ} \mathrm{C},[\alpha]_{\mathrm{D}}-39.9^{\circ}\left(c=0.50, \mathrm{CHCl}_{3}\right) . \mathrm{MS} m / z: 431\left(\mathrm{M}^{+}\right), 416,375,111$ (base peak). IR $v_{\max }^{\mathrm{CHCl}_{3}} \mathrm{~cm}^{-1}: 3400(\mathrm{OH}) .{ }^{1} \mathrm{H}-\mathrm{NMR}\left(100 \mathrm{MHz}, \mathrm{C}_{5} \mathrm{D}_{5} \mathrm{~N}\right) \delta: 0.92(3 \mathrm{H}, \mathrm{d}, J=6 \mathrm{~Hz}, 21-\mathrm{H}), 1.09(3 \mathrm{H}, \mathrm{s}, 19-\mathrm{H}), 1.12$ $(3 \mathrm{H}, \mathrm{d}, J=7 \mathrm{~Hz}, 27-\mathrm{H}), 3.94\left(1 \mathrm{H}, \mathrm{m}, W_{1 / 2}=24 \mathrm{~Hz}, 3 \alpha-\mathrm{H}\right), 4.07\left(1 \mathrm{H}, \mathrm{m}, W_{1 / 2}=8 \mathrm{~Hz}, 6 \alpha-\mathrm{H}\right), 4.30\left(1 \mathrm{H}, \mathrm{m}, W_{1 / 2}=8 \mathrm{~Hz}\right.$, $16 \alpha-\mathrm{H}) .{ }^{13} \mathrm{C}-\mathrm{NMR}\left(22.5 \mathrm{MHz}, \mathrm{C}_{5} \mathrm{D}_{5} \mathrm{~N}\right) \delta: 39.4$ (C-1), 32.4 (C-2), 71.7 (C-3), 36.0 (C-4), $49.5(\mathrm{C}-5), 72.2$ (C-6), 39.7 (C-7), 41.0 (C-8), 58.8 (C-9), 36.5 (C-10), 30.5 (C-11), 38.0 (C-12), 37.3 (C-13), 43.5 (C-14), 32.9 (C-15), 64.8 (C-16), 50.5 (C-17), 62.3 (C-18), 15.0 (C-19), 36.5 (C-20), 14.6 (C-21), 69.6 (C-22), 25.8 (C-23), 29.9 (C-24), 28.7 (C-25), 62.7 (C-26), 18.2 (C-27).

Acetylation of 2 to the Triacetate (2b) - Acetylation of $11 \mathrm{mg}$ of 2 followed by usual work-up afforded $5.1 \mathrm{mg}$

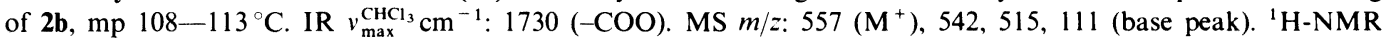
$\left(100 \mathrm{MHz}, \mathrm{CDCl}_{3}\right) \delta: 0.82(3 \mathrm{H}, \mathrm{d}, J=5 \mathrm{~Hz}, 21-\mathrm{H}), 1.03(3 \mathrm{H}, \mathrm{s}, 19-\mathrm{H}), 1.10(3 \mathrm{H}, \mathrm{d}, J=7 \mathrm{~Hz}, 27-\mathrm{H}), 1.98(3 \mathrm{H}, \mathrm{s}$, -OAc), $2.20(6 \mathrm{H}, \mathrm{s},-\mathrm{OAc}), 4.70\left(1 \mathrm{H}, \mathrm{m}, W_{1 / 2}=24 \mathrm{~Hz}, 3 \alpha-\mathrm{H}\right), 5.09\left(1 \mathrm{H}, \mathrm{m}, W_{1 / 2}=8 \mathrm{~Hz}, 16 \alpha-\mathrm{H}\right), 5.21\left(1 \mathrm{H}, \mathrm{m}, W_{1 / 2}=\right.$ $8 \mathrm{~Hz}, 6 \alpha-\mathrm{H})$.

Conversion of 1 to $2-1(17.9 \mathrm{mg})$ was dissolved in $5 \mathrm{ml}$ of $\mathrm{EtOH}$ and was reduced with $\mathrm{NaBH}_{4}$ with stirring for $2 \mathrm{~h}$ at room temperature. The product was extracted with $\mathrm{CHCl}_{3}$ and dried with $\mathrm{Na}_{2} \mathrm{SO}_{4}$, affording $18.3 \mathrm{mg}$ of 2 . mp $269-272{ }^{\circ} \mathrm{C}$.

Compound 3- $\operatorname{mp} 250-256^{\circ} \mathrm{C},[\alpha]_{\mathrm{D}}+0.01^{\circ}\left(c=0.3, \mathrm{CHCl}_{3}\right), \mathrm{MS} m / z: 431\left(\mathrm{M}^{+}\right), 416,204,150$ (base peak).

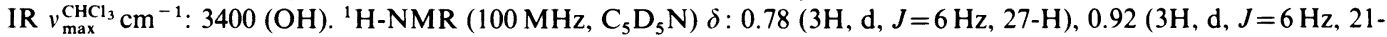
$\mathrm{H}), 0.99(3 \mathrm{H}, \mathrm{s}, 18-\mathrm{H}), 1.63(3 \mathrm{H}, \mathrm{s}, 19-\mathrm{H}), 4.14\left(1 \mathrm{H}, \mathrm{m}, W_{1 / 2}=6 \mathrm{~Hz}, 6 \alpha-\mathrm{H}\right) .{ }^{13} \mathrm{C}-\mathrm{NMR}\left(22.5 \mathrm{MHz}, \mathrm{C}_{5} \mathrm{D}_{5} \mathrm{~N}\right) \delta: 32.4(\mathrm{C}-$ 1), 33.3 (C-2), 67.4 (C-3), 42.3 (C-4), 75.9 (C-5), 76.2 (C-6), 35.9, (C-7), 31.2 (C-8), 46.0 (C-9), 39.3 (C-10), 21.6 (C-11), 40.7 (C-12), 41.1 (C-13), 57.5 (C-14), 33.6 (C-15), 69.3 (C-16), 63.6 (C-17), 17.3 (C-18), 17.2 (C-19), 36.9 (C-20), 18.5 (C-21), 74.7 (C-22), 29.5 (C-23), 31.0 (C-24), 31.5 (C-25), 60.2 (C-26), 19.6 (C-27).

Acetylation of 3 to the Diacetate (3b) $-3(14.7 \mathrm{mg})$ was acetylated in the usual manner to give $15.7 \mathrm{mg}$ of $3 \mathrm{~b} . \mathrm{mp}$ $100-104^{\circ} \mathrm{C}$. MS $m / z: 515\left(\mathrm{M}^{+}\right), 500,204,150$ (base peak). IR $v_{\max }^{\mathrm{CHCl}_{3}} \mathrm{~cm}^{-1}: 3400(\mathrm{OH}), 1700(-\mathrm{COO}) .{ }^{1} \mathrm{H}-\mathrm{NMR}$ $\left(100 \mathrm{MHz} \mathrm{CDCl}_{3}\right) \delta: 0.89(3 \mathrm{H}, \mathrm{d}, J=7 \mathrm{~Hz}, 27-\mathrm{H}), 0.92(3 \mathrm{H}, \mathrm{s}, 18-\mathrm{H}), 0.93(3 \mathrm{H}, \mathrm{d}, J=7 \mathrm{~Hz}, 21-\mathrm{H}), 1.16(3 \mathrm{H}, \mathrm{s}, 19-\mathrm{H})$, $2.03(3 \mathrm{H}, \mathrm{s},-\mathrm{OAc}), 2.12(3 \mathrm{H}, \mathrm{s},-\mathrm{OAc}), 4.67\left(1 \mathrm{H}, \mathrm{m}, W_{1 / 2}=6 \mathrm{~Hz}, 6 \alpha-\mathrm{H}\right), 5.12\left(1 \mathrm{H}, \mathrm{m}, W_{1 / 2}=22 \mathrm{~Hz}, 3 \alpha-\mathrm{H}\right)$.

Hydroxylation of Solanidine (7) to 3 -Hydroxylation of $78.5 \mathrm{mg}$ of 7 was carried out in $5 \mathrm{ml}$ of $88 \%$ performic acid at $75^{\circ} \mathrm{C}$ for $5 \mathrm{~min}$. After the mixture had cooled, $0.5 \mathrm{ml}$ of $\mathrm{H}_{2} \mathrm{O}_{2}$ was added, and the whole was stirred for $30 \mathrm{~min}$ at $35^{\circ} \mathrm{C}$, then further stirred at room temperature overnight. Excess $\mathrm{H}_{2} \mathrm{O}_{2}$ was decomposed with $5 \% \mathrm{Na}_{2} \mathrm{SO}_{3}, \mathrm{NaOH}$ was added, and the mixture was extracted with $\mathrm{CHCl}_{3}$. The formate intermediate was dissolved in $5 \% \mathrm{NaOH}-$ $\mathrm{MeOH}$. This solution was refluxed for $1 \mathrm{~h}$ at $75^{\circ} \mathrm{C}$. The reaction mixture was diluted with $\mathrm{H}_{2} \mathrm{O}$ and extracted with $\mathrm{CHCl}_{3}$ to afford $64.8 \mathrm{mg}$ of $3 . \mathrm{mp} 248-255^{\circ} \mathrm{C}$.

\section{References}

1) Shen-nung-pen-tsao-ching (Shen-nung's Herbal); Chung-yao-chih (Chinese Herbal Drugs) (1979). 
2) K. Kaneko, M. Tanaka, K. Haruki, N. Naruse, and H. Mitsuhashi, Tetrahedron Lett., 39, 3737 (1979).

3) K. Kaneko, N. Naruse, K. Haruki, and H. Mitsuhashi, Chem. Pharm. Bull., 28, 1345 (1980).

4) K. Kaneko, N. Naruse, M. Tanaka, N. Yoshida, and H. Mitsuhashi, Chem. Pharm. Bull., 28, 3711 (1980).

5) K. Kaneko, U. Nakaoka, M. Tanaka, N. Yoshida, and H. Mitsuhashi, Phytochemistry, 20, 157 (1981).

6) K. Kaneko, T. Katsuhara, H. Mitsuhashi, Y.-P. Chen, H.-Y. Hsu, and M. Shiro, Chem. Pharm. Bull., 33, 2614 (1985).

7) K. Kaneko, T. Katsuhara, H. Mitsuhashi, Y.-P. Chen, H.-Y. Hsu, and M. Shiro, Tetrahedron Lett., 27, 2387 (1986).

8) H. Budzikiewicy, Tetrahedron, 20, 2267 (1964).

9) S. Ito, M. Kato, K. Shibata, and T. Nozoe, Chem. Pharm. Bull., 11, 1337 (1963).

10) H. Budzikiewicy, "Structure Elucidation of Natural Products by Mass Spectrometry II," Holden-day, Inc., San Francisco, 1964, p. 10.

11) T. Yamagishi, K. Hayashi, R. Kiyama, and H. Mitsuhashi, Tetrahedron Lett., 39, 4005 (1972).

12) F. Bohlmann, Chem. Ber., 91, 2157 (1958). 